\title{
sobider
}

Sosyal Bilimler Dergisi / The Journal of Social Sciences

Akademik Sosyal Araştırmalar Dergisi, Yıl: 8, Sayı: 50, Şubat 2021, s. 608-625

ISSN: 2149-0821 Doi Number:http://dx.doi.org/10.29228/SOBIDER.49033

\section{Mustafa AYGEN}

Fatih Sultan Mehmet Vakıf Üniversitesi Lisansüstü Eğitim Enstitüsü Temel İslam Bilimleri Anabilim Dalı öğrencisi. mustafaaygen@hotmail.com

\section{KURÂN'I KERIM'DEKİ AHLÂKÎ ÖĞRETILER ÜZERINE BİR INCELEME: "HAYÂ" VE “IFFET" KAVRAMLARI ÖRNEĞİ ${ }^{1}$}

\section{Özet}

\begin{abstract}
Kur'ân-1 Kerîm'in bünyesinde barındırdığg ahlâkî öğretilerin muhataplara sunulmasında öğretici öğeler ve kavramlar kullanılmıştır. Bu öğretiler insan hayatının her anında ortaya çıkan davranışları şekillendirme veya yönlendirme amacı taşımaktadır. Kitapta sunulan bu değerlerin daha iyi anlaşılabilmesi ve bütüncül bir anlama ulaşılabilmesi için, muhatabın karşılaşabileceği durumları ve bu durumlara karşı takınılması gereken tavrı yansıtan bu öğeler ve kavramların semantik ve etimolojik kökenleri hakkında izahat getirilmelidir. Bu çalışmanın konuyu belirli bir sınır çerçevesinde ele alması ve bu çerçevede bütüncül bir sonuca ulaşabilme amacı taşıması sebebiyle, konu -makalemizin de hareket noktası olan- "İffet" ve "Hayâ̂" kavramları üzerinden ele alınacak olup, bu doğrultuda ilk olarak bu kavramların etimolojik kökenlerine inilmesi gerekmektedir
\end{abstract}

Anahtar Kelimeler: Kuran, Ahlâk, Erdem, İffet, Hayâ

\footnotetext{
${ }^{1}$ Bu çalışmanın temeli, Fatih Sultan Mehmet Vakıf Üniversitesi Sosyal Bilimler Enstitüsü Temel İslam Bilimleri Anabilim Dalı Tefsir Bilim Dalı’nda tarafımızca yürütülen (veya yapılmış) doktora tezine dayanmaktadır.
} 


\title{
AN INVESTIGATION ON ETHICAL TEACHING IN THE QURAN: AN EXAMPLE OF THE CONCEPTS OF "CHASTITY" AND "PUDICITY"
}

\begin{abstract}
Didactic elements and concepts were used in presenting the moral teachings contained in the Quran to the addressee. These teachings aim to shape or direct the behaviors that occur at every moment of human life. An explanation should be made about the situations that the addressee may encounter and the semantic and etymological roots of these elements and concepts that reflect the attitude to be taken against these situations for order to better understand the values presented in the book and reach a holistic meaning. Since this study handles the subject within a certain boundary and aims to reach a holistic conclusion within this framework, the subject will be handled over the concepts.
\end{abstract}

Keywords: Quran, ethics, virtue, chastity, pudicity (...)

\section{GİRIŞ}

Kur'ân-1 Kerîm'de yer alan ahlâkî öğretiler, muhatapların hayatlarının bütününe nüfuz eden bir yapıya sahiptir. Zira yüzyıllardır Müslümanlar tarafından okuna gelen ve üzerinde birçok araştırma ve incelemede bulunulan bu kitap, insan hayatına ve fitratına dair rehber niteliğinde birçok gerçeği bünyesinde barındırmaktadır. Peygamber dönemi ve daha önceki tarihi olayları, bu olayların argüman olarak kullanılması yöntemi ile işleyen ve muhatapların hayatı boyunca karşılaşabileceği problemlere öğretici öğeler ve zaman zaman da uyarıcı bir üslupla değinen Kur'ân-1 Kerîm, yapısında barındırdığı bu ahlâkî öğretilerin insan hayatının bütününe nüfuz etmesini talep etmektedir. Bu öğretilerin insan hayatına nasıl nüfuz edeceği ise araştırmalarla ortaya çıkarılması gereken bir sorunsalı teşkil etmektedir. Biz bu makalede bazı kavramlar özelinde bu sorunu ele alıp, Kur'ân-1 Kerîm'de geçen ve çalışmamızda inceleyeceğimiz kavramlar ile Kur'ân-1 Kerîm'in bu yönteminin daha iyi anlaşılmasını amaçlamaktayız.

Kur'ân-1 Kerîm'de yer alan ayetlerde ahlâkî öğretiler çeşitli temsiller ve kavramlar aracılığıyla muhatabın zihninde farkındalık oluşturmayı amaçlamaktadır. Birçok temsilde yer alan ahlâkî kavramlar, muhatap tarafından yapılması istenen ahlâkî davranışları yansıtırken bu kavramların bir kısmı da muhatabın kaçınması gereken ve ahlâkî olmayan davranışları yansıtmaktadır. Muhatap tarafindan yapılması istenen ve onu bu yönde teşvik eden davranışlara misal vermek gerekirse; "Şüphesiz Allah, adaleti, iyilik yapmayı, yakınlara yardım etmeyi emreder, fenalık ve azgınlığı da yasaklar. O, düşünüp tutasınız diye size öğüt veriyor",2 ayeti, inananlara hayatları boyunca birçok meselede diğer insanlara ve tabiata karşı takınmaları gereken tavrı ve tutumu açıklamaktadır. Bir diğer ayet ise, "Güzel söz ve bağışlama, arkasından incitme gelen sadakadan daha iyidir. Allah zengindir, acelesi de yoktur" ${ }^{3}$ şeklindedir. Yine burada Kur'ân-1 Kerîm, insanların davranışlarında takınması gereken tavrı muhatapların her türlü durumunu göz önünde bulundurarak yapmasını ve güzel olana yönelmesini istemektedir.

Kur'ân-1 Kerîm'de muhataplar tarafından kaçınılması istenen tavırlar da çeşitli kavramlarla aktarılmıştır. Örneğin, “Ey iman edenler! Zannın çoğundan sakının; çünkü

\footnotetext{
${ }^{2}$ Fussilet, 41/34

${ }^{3}$ Bakara, 2/263.
} 
bazı zanlar günahtır. Gizlilikleri araştırmayın, birbirinizin gıybetini yapmayın; herhangi biriniz, ölmüş kardeşinin etini yemekten hoşlanır mı? Bak bundan tiksindiniz! Allah'a itaatsizlikten de sakının. Allah tövbeleri çokça kabul etmektedir, rahmeti sonsuzdur." 4 ayetinde insanlarm birbirleriyle olan bireysel ve toplumsal ilişkilerinde dikkat etmeleri gereken hususlardan birkaçı bildirilmektedir. Burada yer alan izahata bakıldığında, insan mahremiyetinin ve insanlar arasındaki güvene dayalı birlikteliğin önemi vurgulanmakta, bu hususların ihlal edilmemesi adına insan doğasına aykırı, caydırıcı örnekler üzerinden somutlama yoluyla sonuca gidilmekte ve muhatabın manevi bir yük ile karşı karşıya kalacağının altı çizilmektedir. Yine Kur'ân-1 Kerîm' de yer alan "Yetimlere nasıl davranacağınız hakkında sana sorarlar. De ki: "Onların durumlarını düzeltmek, onları iyi yetiştirmek en hayırlı olandır. Ve onların hayatlarını paylaşırsanız unutmayın ki, onlar sizin kardeşlerinizdir. Allah bozgunculuk yapanları da düzeltmeye çalışanları da en iyi bilir" ${ }^{\prime 5}$ ve "Doğrusu yetimlerin mallarını haksızca yiyip bitirenler, karınlarına sadece ateş doldurmuş olurlar. Onlar öteki dünyada da çılgın bir ateşe gireceklerdir"6 ayetlerinde ise yetimlere karş1 insanların takınması gerektiği ahlâkî tutum işlenmiştir. İlk ayette insanlar tarafından takınılması tavsiye edilen tutum lafzen olumlu yapıdadır; "Onların durumlarını düzeltmek onları iyi yetiştirmek en hayırlı olandır..." fakat bu cümlenin devamında gelen, "Allah bozgunculuk yapanları da düzeltmeye çalışanları da en iyi bilir." cümlesi aslında burada bir sakınmanın da şiddetle emrolunduğunu göstermektedir. Zira Şâri bu cümleyle sahip olunması gereken ahlâkî tutumu sergilemeyen muhatabın nihayetinde ağır bir cezaya maruz kalacağını işaret etmektedir. Yine yukarıda yer alan diğer ayet ise, aynı konuda insanların sakınması gereken tavrı hem lafzen hem da mana olarak yansitmaktadır.

Konuyla ilgili değinmek istediğimiz bir diğer husus ise, Kur'ân-1 Kerîm'in ahlâkî öğretisini belli bir gayeye matuf olarak muhataplarına indirmesidir. Zira "Câhiliyye" olarak adlandırılan ve vahyin ilk muhatapları olan İslam öncesi Arap toplumu ahlâkî olarak çöküntü ve yozlaşma içerisindeydi. Toplumsal ve sosyal hayatta birçok adaletsizlik ve bozulmalar baş göstermekteydi. Yukarıda yer verdiğimiz ayetlerde dahi bu bozulmalara karşı takınılması gereken doğru tavrı muhataplara tebliğ amacı yer almaktadır. Öyle ki, İslam öncesi Arap toplumunun sosyolojik yapısı eşitsizlik üzerine kurulu olup, her ne kadar gündelik hayatta "şecaat (yiğitlik)", "kerem (soyluluk)", "sehâ (cömertlik" ve "vefâ (sözünde durma)" gibi kavramlar önemli olsalar da bu kavramların kullanıldığı toplumsal zemin farklıydı. Anlaşılacağı üzere İslam öncesinde Araplar arasında husule gelen ahlâkî davranışlarda kibir ve gurur gibi bireysel duygular ön plana çıkmakta ve nihayetinde bu davranışlar kabilenin ve bireyin kendi çıarları doğrultusunda vuku bulmaktaydı. İslam öncesi Arap Toplumunun ahlâkî durumu hakkında bizlere önsezi sağlayacak bir diğer örnek ise cömertlik hususundadır. Cevad Ali'nin el-Mufassal'ında da geçen örnekte, Cahiliye Arapları misafire ikram vermeyi ve cömertlik gösterisinde bulunmayı çoğu kez israf derecesine çıkarıyorlardı. Muâkara dedikleri ve kimin daha çok deve boğazlayıp ikram edeceği üzerine iddiaya girme gibi bir adetleri bulunmaktaydı. $\mathrm{Bu}$ iddia aynı zamanda bir tür kumar olarak görülmekteydi. Taraflardan biri pes edene kadar deve kesilmesine devam edilir ve iddiayı kazanan cömertlikle şöhret bulurdu. ${ }^{7}$ Fakat bu

\footnotetext{
${ }^{4}$ Hucurat, 49/12.

${ }^{5}$ Bakara 2/220.

${ }^{6}$ Nîsa $4 / 10$.

${ }^{7}$ Zengin, Fethullah, Cahiliye Araplarında Bazı Iyi Ahlâk Örnekleri ve Sebepleri Üzerine Bir Değerlendirme, İstanbul, İ.Ü. İlahiyat Fakültesi Dergisi, 2016, s. 53-69.
} 
davranışta, diğer iyi davranışlar gibi belli kaygılarla yapılmaktaydı. ${ }^{8}$ En nihayetinde örneklerden de anlaşılacağı üzere, Arapların toplumsal ilişkilerinde ortaya çıkan ve bütün toplumların tabiatında olan güzel ahlâka dayalı davranışlar İslamiyet öncesi Arap toplumunda sâfiyetini kaybetmişti.

Yukarıdaki pasajlarda da değinildiği üzere, Kur'ân-1 Kerîm'in bünyesinde barındırdığ1 ahlâkî öğretilerin muhataplara sunulmasında öğretici öğeler ve kavramlar kullanılmıştır. Kitapta sunulan değerlerin daha iyi anlaşllabilmesi ve bütüncül bir anlama ulaşılabilmesi için, muhatabın karşılaşabileceği halleri ve bu hallere karşı takınılması gereken tavrı yansıtan bu öğeler ve kavramların semantik ve etimolojik kökenleri hakkında izahat getirilmelidir. Bu çalışmanın konuyu belirli bir sınır çerçevesinde ele alması ve bu çerçevede bütüncül bir sonuca ulaşılabilme amacı taşıması sebebiyle, konu -makalemizin de hareket noktası olan- "Iffet" ve "Hayâ", kavramları üzerinden ele alınacak olup, bu doğrultuda bu kavramların etimolojik kökenlerine inilmesi gerekmektedir.

Çalışmamızın konusuna dair genel bir çerçeve çizdikten sonra, nasıl bir yöntem izleyeceğimiz hususuna da değinmekte fayda görüyoruz. Öncelikle çalışmada kullanacağımız kavramların çerçevesini belirleyeceğiz. Kavramların sözlük ve terim anlamlarının da etimolojik ve semantik incelenmesi yapıldıktan sonra, Kur'ân-1 Kerîm'de yer alan kullanımlarına da yer vereceğiz. Daha sonra ise, konunun daha iyi anlaşllabilmesi adına Kur'an'da iffet ve hayâ kavramları ile eş ve zıt olan kelimeleri araştıracağız. Nihayetinde ise, araştırmamız sonucunda elde ettiğimiz sonucu ve yorumları aktaracağız.

\section{KAVRAMSAL ÇERÇEVE}

Daha önce izah etmeye çalıştığımız hususlar Kur'ân-1 Kerîm'de yer alan ahlâkî öğretilerin anlaşılması noktasında önem arz etmektedir. Bahsettiğimiz üzere, Kurân-1 Kerim'in ayetlerinde muhataplara güzel ahlâka dayalı ögretiler aktarılırken kullanılan belirli yöntemler ve kavramlar bulunmaktadır. Biz bu makalemizde Kur'an'da yer alan bu ahlâkî öğretilerin kavramlar üzerinden aktarılmasını "iffet" ve "hayâ" kavramları üzerinden incelemeye çalışacağız. Bu sebeple ilk olarak bu iki kavramların etimolojisini ve terim anlamlarını inceleyeceğiz.

\subsection{Iffet Kelimesi}

\subsubsection{Sözlük ve Terim Anlamı}

Çalışmamız kapsamında ilk ele alacağımız kavram olan iffet kavramının, Arap dilinde ve Kur'an-1 Kerîm'de yaygın olarak kullanılan " ع ف ف (A-f-f)" kökünden "fi'let" kalıbında mastar olarak türemiş olduğu, sözlükte ise "helal olmayandan uzak olmak"", "helal ve hoş olmayan şeylerden sakınmak", "haramlardan ve süfli isteklerden uzak durmak"10 anlamlarına geldiğini görmekteyiz. İnsanın bedenî ve maddi hazlara aşırı düşkünlükten korunmasını sağlayan erdem için kullanılan bu kelimenin türediği kökün aff, afâfe gibi mastarları da bulunur. 'iffet ve 'afâfe

\footnotetext{
8 Geniş bilgi için bkz. Daha fazla bilgi için bkz. Cevad Ali, el-Mufașsal fî târîhi'l- 'Arab ḳable'l-İslâm, Beyrut, 19681973, IX, 74.

${ }^{9}$ Halil b. Ahmed, Ebu Abdurrahman Halil b. Ahmed el-Ferâhidî, Kitabu'l-Ayn (nşr. Mehdi Mahzumi, İbrâhim Samerrai), Müessesetü'l-Alemi li'l-Matbûât, Beyrut 1988, I, 92.

${ }^{10}$ İbn Manzur, Cemaluddin Muhammed b. Mükrim, Lisanu'l-Arab, Beyrut 1990,1.bsk. c. 9, s., 253;, Mecdüddin Muhammed b. Yakub, el-Kamusu'l-Muhit, Beyrut 1987, s. 1084.
} 
mastarlarının sülâsî mazi sığası 'affe, müzari sığası ye'iffu olup bu fiiller, bir şeyden sakındı, örfe aykırı bir şeyden kaçındı, uzak durdu, namuslu, erdemli, temiz oldu anlamlarını karşılamaktadır.

İffet kelimesinin kendisinden türediği köke oldukça yakın anlamların terim anlamı içerisinde de şekillendiği görülür. Buna göre, ahlâkî bir terim olarak iffet "yeme içme ve cinsî arzu konusunda ölçülü olmak", "aşırı istekleri bastırıp nefsi, dinin ve aklın buyruğu altına sokmak suretiyle kazanılan güzel ahlâk", "nefiste, şehvetin galip gelmesini engelleyen bir halin meydana gelmesi"12 "sıfat olarak şehvetin gücüne engel olup dirayet göstermek ve nefsin aşırılık ve zayıflığına karşı orta yolu tutmak ${ }^{13}$ şeklinde tanımlanır. Ayrıca iffet, "İnsanın arzu ve tutkularını, akıl ve inancının kontrolünde tutmasıdır" şeklinde de tanımlanır. Bu terimin çağrışımları ile ilgili şunları da söylemek mümkündür: "Kişinin Allah ve insanlar nezdinde kendisini küçük düşürecek davranışlardan sakınmasını sağlayan bir erdemdir." "İ "İnsanı bedenî ve maddî hazlara aşırı düşkün olmaktan koruyan bir duygudur."15 "Temizlik ve namustur"16, "Şehvet kuvvetinin itidalidir."," Hüseyin Kazım Kadri’nin (ö.1934) tabirinde iffet, "nefsini şehevâttan saklamak, menhiyattan ve muharremattan imsak-i nefs", taaffüf ise, "iffet ve namusu iltizam etmek, 1rza dokunacak şeylerden sakınmak" diye ifadesini bulur. ${ }^{18}$ İffet'e sahip olan kimselerde afif yahut müteaffif diye vasıflandırılmıştır.

Yukarıdaki tanımlardan da anlaşılacağı üzere Kur'ân-1 Kerîm ahlâkî öğretileri iffet, hayâ ve müstehcenlik gibi çeşitli kavramlar üzerinde muhataplara sunarken aynı zamanda onlardan belli bir sorumluluk düzeyinde olmalarını beklemektedir. "Sorumluluk olgusu ise, iradi ve ihtiyari yönelmenin gerçekleştiği bir zeminde vuku bulmaktadır. O hâlde insanın aşırı zevklerden uzak durmasının iffet ve erdem sayılabilmesi için öncelikle bu tutumun bizzat kendi bilinçli tercihine dayanması ve güçlü bir iradî gayret ile gerçekleştirmesi gerekir. Psikolojik veya bedenî bir zafiyetten, acizlik, korkaklık ve bilgisizlikten yahut başka bir engelden dolayı zevklerini terk eden kişi hakiki anlamda iffetli ve erdemli sayılamaz." ${ }^{19}$ Gazzâlî’ye ait olan bu yorum, Kur'ân-1 Kerîm'in insana yüklediği ahlâklı olma misyonunun sınırlarını tespit edebilme açısından önem arz etmektedir.

Ayrıca düşünce tarihine bakıldığında da peygamberler, filozoflar ve doktorlar da "iffet" kavramına özel olarak vurgu yapmakta, bu haslete sahip olan kişileri övmekte, aksi davranışı ise kötülemekte hemfikirdirler. ${ }^{20}$ Bu konuda örnek vermek gerekirse, Gazzâlî İhyâ'u Ulûmu'd-Dîn adlı eserinde "iffet" kavramına vurgu yapmakta ve bu terimin anlamına uygun düşecek şekilde şu açıklamayı yapmaktadır: "Ahlâkın anası ve esası dört şeydir: Hikmet, şecaât, iffet ve adâlet. Iffet, şehveti akıl ve şeriat kuvvetleri ile terbiye etmektir."21

\footnotetext{
${ }^{11}$ Çă̆rıc1, Mustafa, "İffet”, DİA, XXI, 506.

${ }_{12}$ Rağıb el-İsfehani, Müfredat, Çıra Yayınları, İstanbul, 2007, c.,2, s., 224.

${ }^{13}$ Fihrisu Keşşafu Istılahatil-Fünun Kahraman Yayınları, İstanbul, 1996, s.1010

${ }^{14}$ Çağrıc1, Mustafa, "İslâm Ahlâkı", İlmihâl, TDV Yayınları, Ankara 2008, c.,2, s., 523.

${ }^{15}$ Çağrıc1, "İffet", DİA, XXI, 506

${ }^{16}$ Devellioğlu, Ferit, Osmanlıca- Türkçe Lügat, Aydın Kitabevi Y., Ankara, 1997, s. 411.

${ }^{17}$ Kınalızâde Ali Efendi, Ahlâk, Tercüman Gazetesi Y., İstanbul, ty., s. 94.

${ }^{18}$ Kadri, Hüseyin Kazım, Türk Lugatı, İstanbul 1943, c. III, s. 518.

${ }^{19}$ Ebu Hâmid Muhammed Gazzâlî, İhyau Ulumi'd-Din, İstanbul, Bedir Yayınevi, 1975, III, 105.

${ }^{20}$ Daha fazla bilgi için bkz., Ahmet Rıfat, Tasvîr-i Ahlâk, İstanbul, Tercüman Gazetesi Yayınları, 1988, 179.

${ }^{21}$ Gazzâlî, İhyâ 'u Ulumi'd-Din, II, 127.
} 


\subsubsection{Hayânın Sözlük ve Terim Anlamı}

Kur'ân-1 Kerîm'de yer alan ahlâkî öğretilerin muhataplara aktarılmasında araç olarak kullanılan bir diğer kavram ise hayâdır. Arapça " " kökünden gelen fiil, sözlüklerde utanma, sıkılma, utanç, edep, ar, tevazu namus vb. anlamlarda kullanılmaktadır. ${ }^{22}$ Allâh korkusu ile kötü, çirkin, ahlâk dışı ve günah olan şeylerden kaçınma Canlı olmak ${ }^{23}$, gelişir olmak, (ölümün zıddı) anlamlarına da gelmektedir. "24 "hayy" Fiili toplumun hallerinin, maişetlerinin iyi olması, kavmin otu bol ve sulak bir yere yerleşmesi manasına da gelmektedir. Haya; içten gelen bir ahlaktır, utanma duygusu insanlardan ve Allah'tan korkmaktır. Terim olarak ise hayâ, "Allah'ın razı olmadığ ç̧irkin şeyleri yapmaktan kaçma, başkalarının kötülemelerinden korkma, kötü iş yapınca utanma" demektir. Hayâ kelimesinin etimolojisi hakkında birçok âlim ve düşünür inceleme yapmışlardır. Bu konuda Râğıb el-İsfahânî de, hayâyı "insanın kötülüklerden sıkılması ve onları terk etmesi” şeklinde tanımlamıştır. ${ }^{25}$

Beydâvî, hayayı "çirkin bir şeyden kınanma korkusuyla arız olan ruh darlığıdır."26 diye tanımlarken. Cürcânî, "ayıplanmaktan korktuğu zaman nefsin bir şeyi yapmaktan sakınması ve onu terk etmesi" ${ }^{27}$ diye tarif ettikten sonra biri nefsanî diğeri insanî olmak üzere hayanın iki çeşidinden bahseder. Fîrûzâbâdî ise, "hak sahiplerinin hakkında aşırıya gitmekten ve çirkinliklerden nefsin çekinmesi"28 diye tanımlamıştır. Kadı İyâz, "insanlar nazarında yadırganan ve terkedilmesi hayırlı olan bir işi yaptığı zaman kişinin utancının yüzüne aksettirdiği bir incelik" ${ }^{29}$ olarak ifade etmiştir.

Aynı şekilde günümüz araştırmacılarından Süleyman Uludağ, "Bilerek veya bilmeyerek bir günah işleyen veya hata yapan ya da edep ve ahlaka aykırı davranan bir kimsenin yüzünün kızarmasına ve üzülmesine sebep olan bir histir." ${ }^{\text {30 }}$ Mustafa Çağrıcı ise, "Kınanma endişesiyle kurallara aykırı davranmaktan kaçınma ve bunu sağlayan duygu için kullanılan ahlak terimi" ${ }^{31}$ şeklinde tanımlamaktadır.

\footnotetext{
${ }^{22}$ Ebu'l-Huseyn Ahmed b. Zekeriyyâ İbn Fâris, Mû'cemu Mekâyîsi'l-Luga (I-VI) (nşr. Abdusselâm Muhammed Hârun), Beyrut, Dâru'l-Cîl, 1411/1991, II, s.122; Ebu'l-Kâsım Cârullah Zemahşerî, Mahmûd b. Ömer, Esâsü'lBelâga, Misır, Dâru'l-Fikr, 1406/1985, 3. Bs., I, s. 211; Cemâlüddîn Muhammed b. Mükerrem İbn Manzûr, Lisânu'lArab, Beyrut, Dâru'l-Fikr, 1414/1994, 3. bs., XIV, s. 218; Fîrûzâbâdî, a.g.e., IV, s. 936; Muhibbuddîn Muhammed Murtazâ el-Huseynî el-Vâsıtî ez-Zebîdî, Tâcu'l-Arûs min Cevâhiri'l-Kâmus (I-XX), (Thk. Ali Şîrî), Beyrut, Dâru'lFikr, 1414/1994, IX, s. 359.

2323 İbn Fâris, a.g.e., II, s. 122; İbn Manzûr, a.g.e. XIV, s. 212; Fîrûzâbâdî, a.g.e., IV, s. 934; ez-Zebîdî, a.g.e., IX, s. 357.

${ }^{24}$ İbn Manzûr, a.g.e, XIV, s. 213; Fîrûzâbâdî, a.g.e, IV, s. 935.

${ }^{25}$ Râgıb el-İsfehânî, a.g.e., s. 199.

${ }^{26}$ Beydâvî, Nâsiruddin Abdullah b. Ömer, Tefsîru'l Beydâvî (1-2), Dâru'l-Kütübi’l-İlmiyye, Beyrut 1406/1988, 1. Bask1, , c.I, s.56.

${ }^{27}$ Cürcânî, es-Seyyid eş-Şerîf Ali b. Muhammed, Kitabu't-Ta'rîfât (nşr. Abdulmun'im el-Hufnâ), Dâru'r- Reşâd ,Kahire, 1991, s. 65.

Fîruzâbâdî, Mecduddin Muhammed b. Ya'kûb, Besâir Zevi't-Temyîz fî Letâifi'l-Kitâbi'l-Azîz (nşr. Muhammed Ali en-Neccâr), 1-6, el-Mektebetü'l-İlmiyye, Beyrut, ts., c.2,s. 515.

${ }^{29}$ Kadı İyâz, eş-Şifâ bi Ta'rîfi Hukûki'l-Mustafâ, (Tercüme ve Notlar: Suat Cebeci), Rehber Y., Ankara, ts. s.93.

${ }^{30}$ Uludağ, Süleyman, Ahlak, Maneviyat ve Gündelik Hayat, İslam'a Giriş Temel Esaslar, DİB Yay, Ankara, 2008, s.375.

${ }^{31}$ Çağrıc1, Mustafa, “ Haya”, TDV Yay, İstanbul 1997, c. 16, s. 554.
} 
İffet'e götüren utanma hissinin aynı zamanda hayâ ve yüksek ahlâkî erdemlerin tam olarak tezahür ettiği zat, şüphesiz ki, Hz. Peygamberdir. Bu konuda ondan nakledilen hadîs-i şerîf'lerde yer alan kullanımlar önem arz etmektedir. Bu yüzden, "hayâ" kavramının kullanımına dair verdiğimiz örneklere Peygamberimiz 'den nakledilen hadîs-i şerîfleri de de örnek gösterebiliriz. Bu metinlerde Peygamber'in sahip olduğu ve muhataplardan da sahip olmasını istediği ahlâkî özellikler "hayâ" kelimesiyle dile getirilmiştir. Mesela Tirmîzî'de geçen; "Kendisine karşı hayâ edilmeye Allah daha lâyıktır" koymaktadır.

\section{KURÂN-I KERÎM'DE İFFET VE HAYÂ}

Kurân-1 Kerîm'de "iffet" ve "hayâ" kavramlarının kullanımına dair değişik örnekler mevcuttur ve bu örneklerin farklı kullanılış şekilleri bulunmaktadır. Bu kelimeler hem aynı köklerden türetilen sözcükler hem de farklı farklı köklerden türetilen sözcüklerle ifade edilen fakat aynı anlama gelen kullanımlarda yer aldığı gibi, söz konusu kullanımlarda kavramların eş ve zit anlamını gösteren kelimeler olarak veya her iki kavrama anlam olarak yakın olan kelimeler olarak da geçmektedir. Bunun yanı sıra hayâ şeklinde ifade edilmesine rağmen iffet ile aynı anlamda kullanılmayan ifadelere de rastlamaktayız.

Aşağıda, Kur'an'da "iffet" ve "hayâ" kavramları ile ilgili geçen ayetleri, aynı zamanda bu kavramların eş ve zit anlamlarını inceleyeceğiz.

\subsection{Kurân-ı Kerîm'de İffet Kavramı}

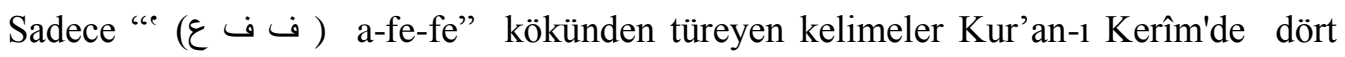
yerde geçmektedir. Bu kelimelerde aslında birebir "iffet kelimesi olmayıp, a-fe-fe kökünden

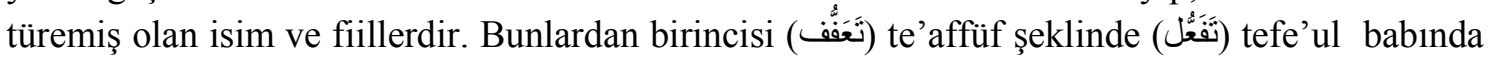

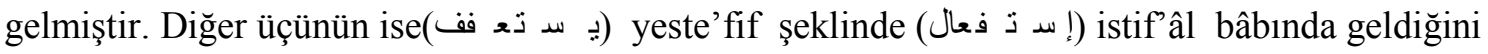
görmekteyiz. Bunlar sırasıyla aşağıdaki şekilde geçmektedir.

Birincisi Bakara suresinde geçen ve teaffüf kalıbında gelen kavram Allah yolunda cihada çıkmaları sebebiyle rızıkları için gereken işlerle meşgul olamayıp fakir kalan iffetli kimseleri anlatmaktadır. Bu gruptaki kimseler İslâm'ın vakarına haiz olduklarından dolayı ihtiyaçları için kimseye el açmamışlar ve herhangi bir yardım talebinde bulunmamışlardır. Aynı zamanda bu iffetli müminler öylesine tok gözlüdürlerki haklarında ayrıntılı bilgi sahibi olmayıp da sadece dışarıdan kendilerini gören kimseler onları zengin zannetmekte idiler. İlgili ayet mevzuyu şu şekilde anlatır:

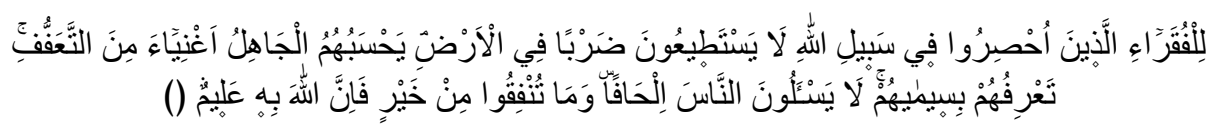

"Yapacağınız hayırlar, kendilerini Allah yoluna adamış, bu sebeple yeryüzünde kazanç için dolaşamayan fakirler için olsun. Bilmeyen kimseler, iffetlerinden dolayı onları zengin zanneder. Sen onları simalarından tanırsın. Çünkü onlar yüzsüzlük ederek istemezler. Yaptı̆̆ınız her hayrı muhakkak Allah bilmektedir. "33

\footnotetext{
${ }^{32}$ Ebû Îsâ Muhammed b. Îsâ b. Sevre (Yezîd) et-Tirmizî, el- Câmiu's- Sahih, (nşr. Ahmed Muhammed Şâkir v.dğr.), Kahire, 1356/1937. "Edeb" 22, Hadis No: 2769, c.3, s. 20.

${ }^{33}$ Bakara $2 / 273$.
} 
Yine benzeri bir ayet yetimlerin veliliğini ve hamiliğini yapan kişilerle ilgilidir.

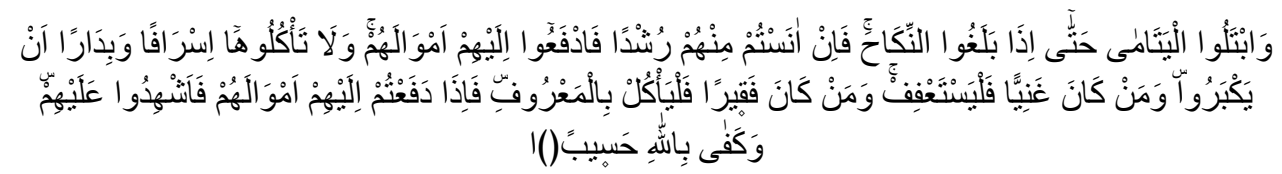

Yetimleri deneyin. Evlenme çă̆ına (buluğa) erdiklerinde, eğer reşit olduklarını görürseniz, mallarını kendilerine verin. Büyüyecekler (ve mallarını geri alacaklar) diye israf ederek ve aceleye getirerek mallartn yemeyin. (Velilerden) kim zengin ise (yetim malından yemeğe) tenezzül etmesin. Kim de fakir ise, aklın ve dinin gereklerine uygun bir biçimde (hizmetinin karşılı̆̆ı kadar) yesin. Mallarını kendilerine geri verdiğiniz zaman da yanlarında şahit bulundurun. Hesap görücü olarak Allah yeter. ${ }^{34}$

Ayetin işaret ettiği kadarıyla normal şartlarda yetimin velisi olan ve onun mallarını koruyup kollayan kimselerin ihtiyaç durumunda bu mallardan ihtiyaçları oranında istifade edebileceğini hükme bağlamıştır. Eğer böyle olmaz ise kimse kendi işini gücünü bırakıp yetimler ile ilgilenmez. Bu ise onların korumasız kalıp kötü niyetli insanların eline düşmesine sebebiyet verir. Ancak kişi yetimin malından yararlanacağı zaman çok dikkatli olmalıdır. İşte Kur'an-1 Kerîm bu hususa işaret ederken önce zengin velilerin durumuna dikkat çeker ve "kim zengin ise tok gözlülük göstersin ve yetimin malına ilişmesin” anlamında "yeste'fif” kelimesini emir kipinde kullanır. Fakir olanların ise yetimlerin mallarında tasarrufta bulunurken ve onları işletirken bu mallardan şahsı için örf ölçüsünde yararlanmasını ister. Ayrıca burada "ye'kül/yesin" kelimesini kullanarak bir bakıma bu mallardan sadece gida cinsinden yemeiçmeye dair zaruri ihtiyaçların karşılamasını nasihat eder.

Görüldüğ̈̈ üzere yukarıdaki ayetlerde teaffüf ve yesta'fif kelimeleri "sabırlı olup tok gözlü olmak", "kanaatkâr davranmak", "açgözlülükte bulunmamak" anlamlarına gelmektedir. bu anlamlar iffet lafzı ile dolaylı yoldan ilgili olsalar da "utanma", "hicab etme", "haya duyma" anlamlarındaki iffet kelimesinden farklı kullanımlara sahiptirler. Buna istinaden Semîn elHalebî (ö. 756/1355) vücûh ve nezâire dair kitabında bu iki kavramın eşit anlam ifade ettiğini ve "kanaatkârlıkta sebat etmek ve sabır göstermek" anlamına geldiğini ifade eder. Kitabında naklettiği bir tanıma göre teaffüf ve isti'faf , "kişinin nefsinde ortaya çıkan ve kişiyi şehvetin (arzuların) kendisine üstün gelmesinden engelleyen haldir" anlamlarına gelmektedir. ${ }^{35}$

Ragıp el-İsfehanî (ö. 425/1036 civarı) ise, Kur'an-1 Kerîm'deki iffetli olmayı isteme anlamındaki "isti'faf" lafzını, bir çeşit alışkanlık kazanarak, bir disiplin içinde ruhunda iffet erdemini geliştirmeye çalışma şeklinde izah eder. ${ }^{36}$

Bu iki anlam dişında Kur'an'da isti'fâf şeklinde geçen ve utanma, ar duyma, kendini yanlış ahlaki davranışlardan koruma anlamlarında gelen bir başka kullanıma da Nûr sûresinde bekârların evlenmesine dair anlatılan ayetlerde rastlamaktayız. Söz konusu âyetlerde evlenmeye imkân bulamayanların bu imkân ellerine geçinceye kadar iffetli davranmaları gerektiği bildirilir. İlgili âyetin geçtiği çerçeve şu şekilde ortaya konulmuştur:

\footnotetext{
${ }^{34}$ Nisa, 4/6.

${ }^{35}$ Ebü'l-Abbas Şehabeddin Ahmed b. Yusuf b. Abdiddaim Semîn el-Halebî, Umdetü'l-huffaz fí tefsiri eşrefi'l-elfaz. (nşr. Muhammed Bâsil Uyûnü's-Sûd), Beyrut, Dârü'l-Kütübi'l-İlmiyye, 1417/1996, III, s. 97.

${ }^{36}$ Râgıb el-İsfahânî, Müfredâtü elfâzi 'l-Kưr 'ân (nşr. Safvân Adnân Dâvûdî), Dımaşk-Beyrut 1412/1992, s. 342.
} 


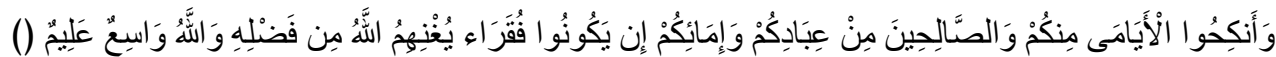

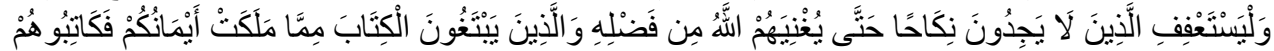

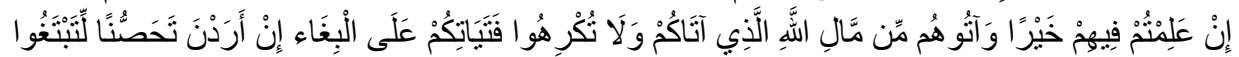

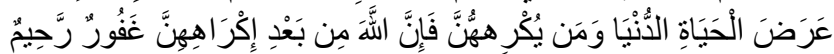

"Sizden bekâr olanları, kölelerinizden ve cariyelerinizden durumu uygun olanları evlendirin. Eğer bunlar yoksul iseler, Allah onları lütfuyla zenginleştirir. Allah, lütfu geniş olandır, hakkıyla bilendir. Evlenmeye güçleri yetmeyenler de Allah kendilerini lütfuyla zengin edinceye kadar iffetlerini korusunlar. Sahip olduğunuz kölelerden "mükâtebe" yapmak isteyenlere gelince, ĕger onlarda bir hayır görürseniz onlarla mükâtebe yapın. Allah'ın size verdiği maldan onlara verin. Dünya hayatının geçici menfaatlerini elde etmek için iffetli olmak isteyen cariyelerinizi fuhşa zorlamayın. Kim onları buna zorlarsa bilinmelidir ki hiç şüphesiz onların zorlanmasından sonra Allah (onları) çok bağışlayıcıdır, çok merhametlidir. ${ }^{, 37}$

Yine sürenin bir diğer ayetinde ise isti' fâf kelimesi yaşlı olup da artık kimsenin kendisi ile evlenmeyi düşünmeyeceği cazibesini kaybetmiş kadınların örtünmesi konusunda diğer kadınlar gibi olmadığı bunların isterlerse örtülerini diğer kadınlar gibi örtmeyecekleri ifade edildikten sonra yine de iffetli davranıp örtülü olmalarının daha hayırlı olacağı vurgulanmıştır. Zaten ayetin devamından iffetli olmayı isteme (isti'fâf) kabilinden yaşlı kadıların bile örtüsünü alıp diğer Müslüman kadınlar gibi davranması iffetli bir davranış olarak gösterilmiştir. Buna göre kadının örtünmesi aynı zamanda onun iffeti olarak da vurgulanır. Durum böyle olunca örtünmenin Allah'ın emri olduğu halde örtünmeme iffetsizlik şeklinde algılanmaktadır. İleride de üzerinde durulacağı üzere iffet, haya, açıklık-saçıklık (müstehcenlik) hep birbiri ile ilişkili konulardır. İlgili ayet şu şekildedir.

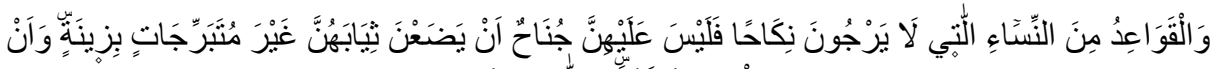

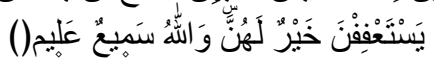

Bir nikâh ümidi kalmayan, çocuktan kesilmiş yaşlı kadınların ise, ziynetlerini (yabancı erkeklere) göstermeksizin dış elbiselerini çıkarmalarında kendilerine bir vebal yoktur. Yine de iffetli olmaları kendileri için daha hayırlıdır. Allah işitendir, bilendir $^{38}$

“Iffet" kavramının yukarıda gösterdiğimiz anlatımları dışında Kur'an'ın diğer ayetlerinde geçen örnekleri ise şu şekildedir:

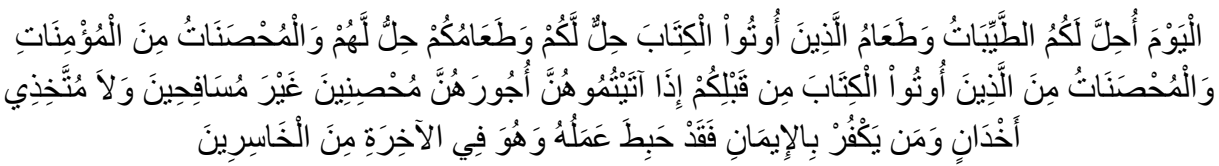

"Bugün size temiz ve iyi şeyler helâl kilınmıştır. Kendilerine kitap verilenlerin (Yahudi, Hristiyan vb. nin) yiyeceği size helâldir, sizin yiyeceğiniz de onlara

\footnotetext{
37 en-Nûr 24/32-33.

38 en-Nûr $24 / 60$
} 
helâldir. Mümin kadınlardan iffetli olanlar ile daha önce kendilerine kitap verilenlerden iffetli kadınlar da mehirlerini vermeniz şartıyla, namuslu olmak, zina etmemek ve gizli dost tutmamak üzere size helâldir. Kim (İslâmî hükümlere) inanmayı kabul etmezse onun ameli boşa gitmişstir. $O$, ahirette de ziyana uğrayanlardandir. ${ }^{, 39}$

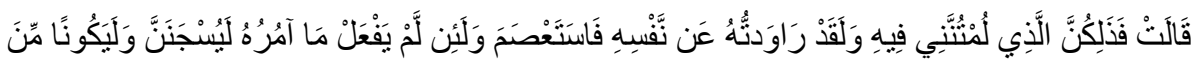

$$
\begin{aligned}
& \text { الصَّاغرِِِينَ }
\end{aligned}
$$

"Vezirin karısı: "IŞste sözünü edip beni yerdiğiniz budur. Andolsun ki onun olmak istedim, fakat o iffetinden dolay çekindi. Emrimi yine yapmazsa, andolsun ki hapse tıkılacak ve kahre uğrayanlardan olacak. "A0

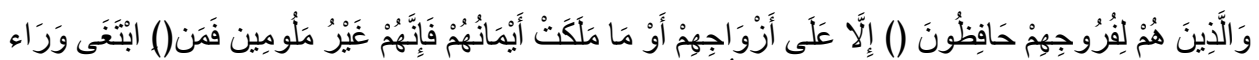

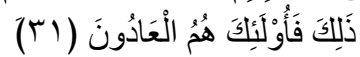

"Irzlarını korurlar. (aslâ zinâ etmezler) Yalnı eşlerine ya da ellerinin altında bulunan (câriyelerin)e karşı (korumazlar. Çünkü onlar helâldir. Böyle yapmalarından ötürü de) ayıplanmazlar. Bu stnırları aşmak isteyenler, işte onlar, aşıı gidenlerdir. ${ }^{, 41}$

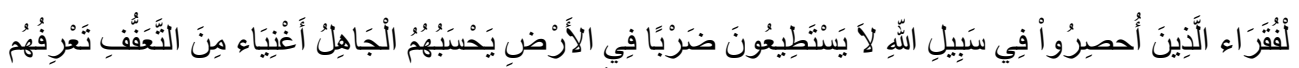

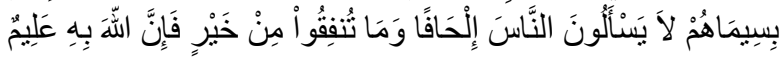

“(Sadakalar) kendilerini Allah yoluna adayan, yeryüzünde dolaşmaya gü̧ yetiremeyen fakirler içindir. Iffetlerinden dolayı (dilenmedikleri için), bilmeyen onlarl zengin sanır. Sen onlarl yüzlerinden tanırsın. Insanlardan arsızca (bir şey) istemezler. Siz hayır olarak ne verirseniz, şüphesiz Allah onu bilir. ",2

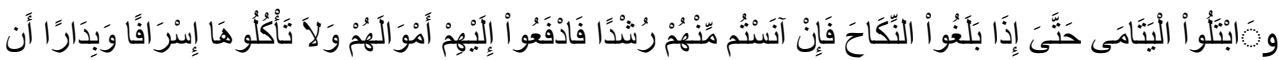

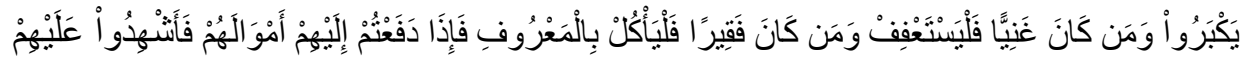

$$
\begin{aligned}
& \text { وَكَفَى بِالَّهِ حَبِيبًا }
\end{aligned}
$$

Yetimleri deneyin. Evlenme çă̆ına (buluğa) erdiklerinde, ĕ̆er reşit olduklarını görürseniz, mallarını kendilerine verin. Büyüyecekler (ve mallarını geri alacaklar) diye israf ederek ve aceleye getirerek malların yemeyin. (Velilerden) kim zengin ise (yetim malından yemeğe) tenezzül etmesin. Kim de fakir ise, aklın ve dinin gereklerine uygun bir biçimde (hizmetinin karşılı̆̆ kadar) yesin. Mallarını kendilerine geri verdiğiniz zaman da yanlarında şahit bulundurun. Hesap görücü olarak Allah yeter. ${ }^{43}$

\subsection{Kur'ân-ı Kerîm'de Hayâ Kavramı}

İslam dininin, imanın bir parçası olarak gördüğü ve bir Müslümanın imanını kemale götüren en önemli hasletlerden biri olarak bilinen "hayâ" kavramı hem kelimenin kendisi olarak hem de hayâ sözcüğü ile eş anlamı taşıyan kelimeler olarak Kur’an'da birçok yerde

\footnotetext{
${ }^{39}$ el-Maide 5/5

${ }^{40}$ Yusuf $12 / 32$

${ }^{41}$ el-Mearic 70/29-31

42 el-Bakara $2 / 273$

43 en-Nisa $4 / 6$
} 
geçmektedir. Şöyle ki, " "Ha-Yi-Ye" kökünden müştak kelimelerin büyük bir bölümü hayat, yaşamak, diri ve canlı olmak mânâlarında kullanılmıştır. Bunun yanında diğer anlamlar olarak ta diriltmek, yaşatmak, öldürmeyi terk etmek, sağ bırakmak, selamlamak, selam, esenlik dileği, sıfat olarak Allah'a (c.c) atfedilerek "Hayy" olarak kullanılmıştır. ${ }^{44}$

Hayâ kelimesi, utanmak, çekinmek, hayâ duymak anlamında Kur'an'da sadece üç ayette kullanılmaktadır. Çalışmamızı daha çok ilgilendirmesi bakımından bu başlık altında ilk olarak bu üç ayeti sıralayacağız. Söz konusu ayetler;

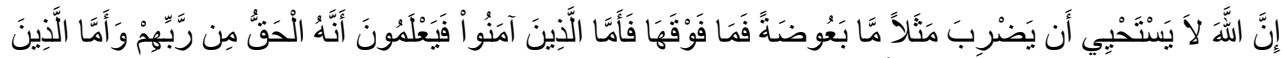

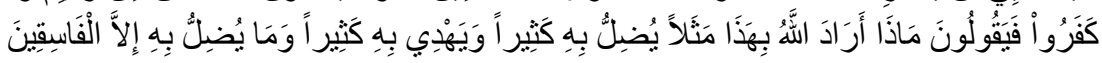

"Allah sivrisineği ve onun üstününü misal olarak vermekten çekinmez (haya duymaz). Inananlar bunun Rablerinden bir gerçek olduğunu bilirler. İkâr edenler ise "Allah bu misalle neyi murad etti?" derler, O, bu misalle birçoğunu saptırır, birçoğunu da yola getirir. Onunla saptırdiğ yalnız fasıklardır ki onlar Allah'la yapılan sözleşmeyi kabulden sonra bozarlar. Allah'ın birleştirilmesini buyurduğu şeyi ayırırlar ve yeryüzünde bozgunculuk yaparlar; zarara uğrayanlar işte onlardir. ${ }^{, 45}$

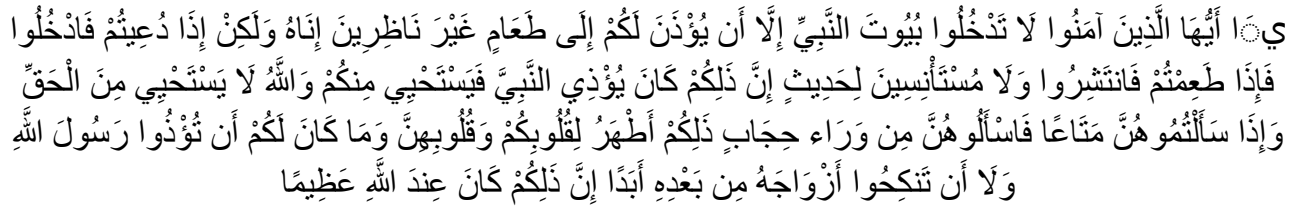

"Ey inananlar! Peygamber'in evlerine, yemeğe çağırllmaksızın vakitli vakitsiz girmeyin; fakat davet edilseniz girin ve yemeği yiyince, dağllın. Sohbet etmek için de girip oturmayın. Bu haliniz Peygamber'i üzüyor, o da size bir şey söylemeye çekiniyordu. Allah gerçeği söylemekten çekinmez. Peygamber'in eşlerinden bir şey isteyeceğinizde onu perde arkasından isteyin. Bu sayede sizin gönülleriniz de onların gönülleri de daha temiz kalır. Bundan sonra ne Allah'ın Peygamber'ini üzmeniz ve ne de O'nun eşlerini nikahlamanız asla caiz değildir. Doğrusu bu, Allah katında büyük şeydir. " ${ }^{46}$

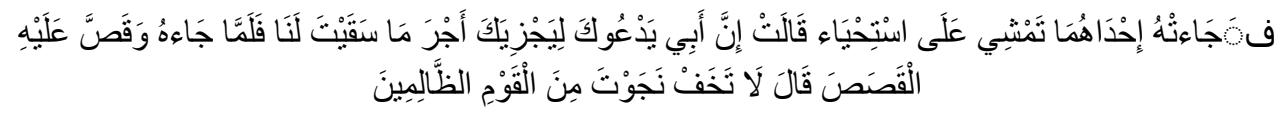

"O sırada, kadinlardan biri utana utana yürüyüp ona geldi: "Babam sana sulama ücretini ödemek için seni çağırıyor" dedi. Musa ona gelince, başından geçeni anlattı. O: "Korkma, artık zalim milletten kurtuldun" dedi., ,47

\footnotetext{
${ }^{44}$ Geniş bilgi için bkz. Muhammed Fuad Abdulbaki, el-Mu'cemü'l-Müfehres li Elfâzi'l-Kur'âni'l-Kerîm, Kahire, Dâru'l-Hadîs, 2001, s.273-177.

45 el-Bakara $2 / 26$

${ }^{46}$ Ahzab 33/53.

47 el-Kasas $28 / 25$
} 
Gördügümüz kadarıyla ha-yi-ye (ي-ح-ح) şeklinde geçen haya kavramı yukarıdaki iki ayette iffet kavramını kapsamı içine almaktadır. ha-yi-ye (ي-ح) şeklinde geçmeyen iffet kavramının zıt anlamı olan iffetsizlik ve hayasızlık anlamlarını içeren ayetlere örnek olarak ise şu ayetler gösterilebilir;

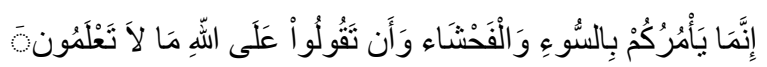

"O sizi hep çirkin işler ve hayâsızlık yapmaya, bir de Allah hakkında bilmediğiniz şeyleri iddia etmeye teşvik eder." ${ }^{48}$

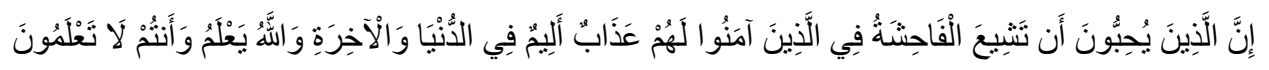

"İnananlar arasında hayâsızlığın yayılmasını arzu eden kimseler var ya; onlar için dünya ve ahirette elem dolu bir azap vardır. Allah bilir, siz bilmezsiniz." ${ }^{49}$

\section{KELIMELER}

4. KUR'AN'DA IFFET VE HAYÂ KAVRAMLARI ILE EŞ VE ZIT OLAN

Bu bölümde özet olarak utanmak, belaya girmek, rezil rüsva olmak, hayrete düşmek, sıkıntıya girmek gibi iffet ve haya kelimeleriyle ilgili olduğuduğunu düşündüğümüz eş ve zıt anlamlı kelimelerden bazı örnekleri ortaya koymaya çalışacağız. Fakat konuya başlamadan önce farklı kelimelerin anlam olarak birbirine yakın olmasına rağmen tam olarak istenilen manay 1 veremediği gerçeğinin unutulmamasını da hatırlatmak gerekir.

\section{1. İffet Kavramıla Eş Anlamlı Olanlar}

Kur'an-1 Kerimde iffet ile ilgili olarak üçü yakın ikisi ise zıt anlamlı olmak üzere toplamda beş kavram bulunmaktadır. Bu kelime ayetlerde "فَرْجَ" ", "ferc" kelimesiyle birlikte geldiği gibi bu fiilin ismi faili olarak da gelmiştir. Kavramın bulunduğu bir ayet Tahrim süresinde şöyle geçmektedirdir:

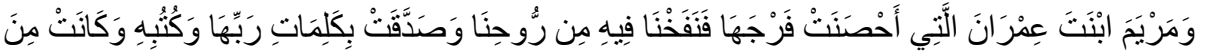

$$
\begin{aligned}
& \text { الْقَانتينَنَ }
\end{aligned}
$$

"Bir de Imrân kazı Meryem'i (misal vermiştir): O iffetini çok iyi korumuştu, biz de ona ruhumuzdan üfledik; o, rabbinin sözlerini ve kitaplarını hep tasdik etti ve o içtenlikle itaat edenlerdendi. ${ }^{\prime \prime 50}$

Ayette geçen "حَصَنَ", "ahsene" fiili "فَرْجَ", "ferc" kelimesiyle birlikte gelerek namusunu çok iyi korudu anlamında kullanılmıştır.

İkinci olarak geçtiği ayette ise "a-s-m" fiilinin "istifâl" kalıbındaki "اسنَتََْْمَ, şeklindeki kullanımı vardır. "a-s-m" fiili sözlükte, sahip olmak, önlemek, korumak ${ }^{51}$ anlamlarına gelirken "istifâl" kalıbındaki anlamı "günahtan kaçınmak" ${ }^{52}$ şeklinde gelmiştir. Yusuf suresi 32. ayetinde:

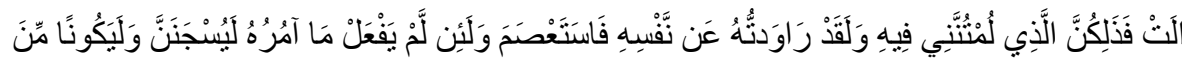

$$
\begin{aligned}
& \text { الصَّاغِرِينَ }
\end{aligned}
$$

\footnotetext{
48 el-Bakara 2/169.

49 en-Nûr 24/19.

${ }^{50}$ Tahrim, 66/12.

${ }^{51}$ Firuzabadi, age., s.1469.

${ }^{52}$ Mutçalı, Serdar, Arapça-Türkçe Okul Sözlüğü, Dağarcık Yayınları, İstanbul, 1997, s. 335.
} 
"Kadın dedi ki: "İşte hakkında beni kınadı̆̆ınız şahıs budur. Ben onun nefsinden murat almak istedim. Fakat o, iffetini korudu, Andolsun, ĕger kendisine emredeceğimi yapmazsa, mutlaka zindana atılacak ve elbette sürünenlerden olacaktır!" ${ }^{53}$

Üçüncü olarak ise "h-f-z" fiilinin "ferc" kelimesiyle kullanılmasıdır. Tekil veya çoğul gibi çeşitli kalıplarda gelen "fercin muhafazası, korunması" anlamındaki sözlerdir. Iffet anlamı içeren birçok ayette geçmektedir. ${ }^{54}$ Örnek olarak Ahzab süresin 35. Ayette de Allah(c.c) şöyle buyurur:

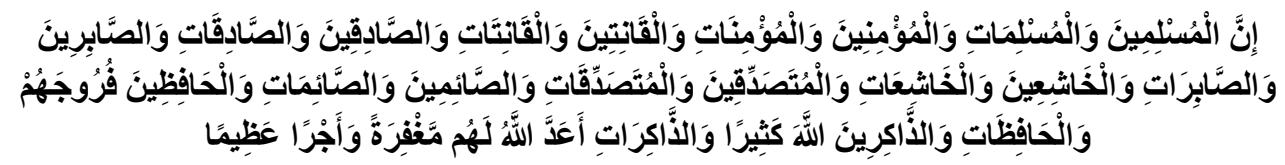

"Şüphe yok ki, Íslâmiyet'i kabul eden erkekler ve İslâmiyet'i kabul eden kadınlar ve imân eden erkekler ve imân eden kadinlar ve itaate müdavim, erkekler ve itaate devam eden kadınlar ve sadakatli erkekler ve sadakatli kadınlar ve sabırlı erkekler ve sabırlı kadınlar ve hak için mütevazı erkekler ve tevazuda bulunan kadınlar ve sadaka veren erkekler ve tasaddukta bulunan kadınlar ve oruç tutan erkekler ve oruçlu kadınlar ve namuslarını koruyan erkekler ile namuslarını muhafaza eyleyen kadınlar ve Allah Teâlâ'y çokça zikreden erkekler ve zikreyleyen kadınlar -var yaonlar için Allah Teâlâ bir mağfiret ve pek büyük bir mükâfat hazırlamıştır. "55

Ayette geçen وَالْحَافِظِينَ فُرُوجَهُمْ وَالْحَفِظَاتِ ", "hâfizîne fürûcehum ve'l-hâfizât" kelime gurubunun karşılığı olarak "iffetlerini koruyan erkekler ve kadınlar" lafzı kullanılmıştır. "H-f-z" kelimesi, "Korumak, kaydetmek" gibi anlamları içerir. "F-r-c" ise iki şey arasındaki yarıktır. Bu kelime ile edep yerinden kinaye yapılmaktadır; bu anlamda çok kullanıldı̆̆ından dolayı artık onun için sarih bir isim olmuştur. ${ }^{56}$

\section{2. İffet Kavramiyla Zit Anlamlı Olanlar}

Bir kavramın iyi anlaşılabilmesi için, onun eş anlamını bilmek kadar zıt anlamını bilmek de çok önemlidir. Bu durumda, iffet kavramının kapsadığı anlam alanının iyice öğrenilmesi amacıyla, onunla zit anlama gelen bazı kavramlarının da incelenmesinin faydalı olacağı kanaatindeyiz.

İffetin zıttı olarak Kur'an'da iki kavram bulunmaktadır. Bu kavramlardan biri "f-h-ş" kökünden çeşitli türevleriyle gelen kelimelerdir. "F-h-ş" kelimesi "çok çirkin/kötü olan söz ve fiillerdir." ${ }^{57}$ Kur'an-1 Kerim'de çirkin iş, ${ }^{58}$ suç $^{59}$, kötü, kötülük ${ }^{60}$, haddi aşmak ${ }^{61}$, ,fuhuş ${ }^{62}$ zina $^{63}$

\footnotetext{
${ }^{53}$ Yusuf $12 / 32$.

${ }^{54}$ Mü'minûn, 23/5; Nûr, 24/30, 31; Ahzâb, 33/35; Mearic, 70/29.

${ }^{55}$ Ahzâb, 33/35.

${ }^{56}$ İsfehani, age., II, 317.

${ }^{57}$ İsfehani, age., c. $2,314$.

${ }^{58}$ Bakara, 2/169, 268; Nisâ, 4/22; İsrâ, 17/32; Ankebût, 29/28; Şûrâ, 42/37.

59 Âl-i İmrân, 3/135.
} 
ve edepsizlik, iffetsizlik ,hayasızlık, ${ }^{64}$ anlamlarında kullanılmıştır. Nahl suresi 90. Ayete baktığımızda;

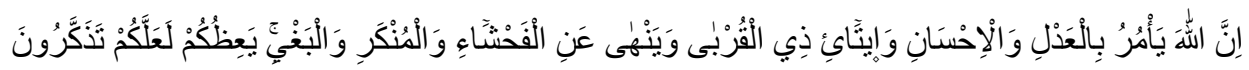

Muhakkak ki Allah, adaleti, iyiliği, akrabaya yardım etmeyi emreder, çirkin işleri, fenalık ve azgınlığı da yasaklar. $O$, düşünüp tutasınız diye size ögüt veriyor ${ }^{65}$

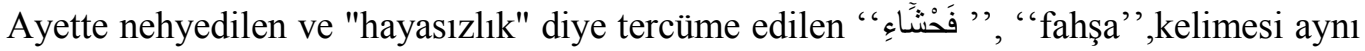
kökten gelen "fuhuş" kelimesiyle eş anlamlıdır ve çirkin sözler ve fiiller için kullanılmıştır. Daha genel bir ifadeyle fahşâ, başta zina olmak üzere edep, iffet ve haya 'ya aykırı her türlü söz ve fiilleri ifade etmektedir. ${ }^{66}$ Ayetten anlaşılan aslında aynı zamanda bir iffet erdemidir. Fahşa kelimesiyle ilgili bir diğer Ayette şöyle buyrulmuştur:

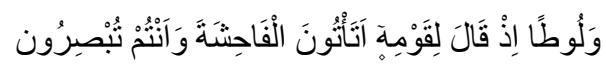

Lût'u da hatırla! O kavmine, "Göz göre göre hâlâ o hayasızlı̆̆ yapacak misınız? Gerçekten siz kadınları bırakıp da şehvetle erkeklere mi yönetiyorsunuz? Doğrusu siz değerleri bilmez cahil bir topluluksunuz!" demişti ${ }^{67}$

Aynı şekilde ayetteki "fâhişete" kelimesi Lut kavminin içinde bulunduğu bu iğrenç denebilecek gayr-i ahlaki durumu özetlemektedir.Şehvetin nikâhlı olan kadına gösterilmesi bir sınır iken, bunu nikâhı olmayan bir kadına hatta kendi cinsinden olan bir erkeğe göstermek haddi aşmış olmanın en uç noktası demektir. "Cinsel sapıklığı hayatlarının tek ölçüsü ve amacı haline getiren, nefislerinin gayr-i meşru istekleri uğruna ahlak, fazilet, namus, iffet ve her türlü edep ve terbiye sınırlarını aşmakta bir sakınca görmeyen azgın, inkârcı, sapık bir milletin durumu açıklanmaktadır." ${ }^{68}$ Birçok kötülüklerin yanında homoseksüellik gibi yasaklanmış bir ilişkiye alışmış olan ve peygamberin uyarılarına kulak vermeyen bir topluluğun nasıl helak edildiği anlatılarak insanların bu tür kötülüklerden sakınmaları istenmektedir.

İffet kavramının zit anlamlısı olarak Kur'an'da geçen ikinci bir kavram ise "b-ğ-y" kökünden ismi fâil olarak gelen kelimedir. İki ayette şöyle geçmektedir:

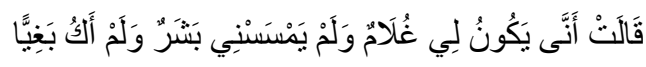

"Meryem ise "Bana bir erkek eli değmediği halde nasil çocuğum olur? Ben iffetsiz de değilim" dedi, ${ }^{69 "}$

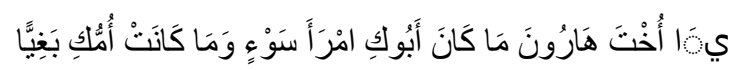

"Ey Harun'un kız kardeşi! Baban kötü bir adam değildi; annen de iffetsiz değildi. "70

\footnotetext{
${ }^{60}$ En'âm, 6/151; Yusuf, 12/24; Nûr, 24/21.

${ }^{61}$ A'râf $7 / 28,80$.

${ }^{62}$ Nisâ, $4 / 25$.

${ }^{63}$ Nisâ $4 / 15,19$.

${ }^{64}$ A'râf, 7/28, 33; Nahl, 16/90; Nûr, 24/19; Neml, 27/54; Ankebût, 29/45; Ahzâb, 33/30; Necm, 53/32

${ }^{65}$ Nahl, 16/90

${ }^{66}$ İsfahan1, a.g.e., "fhş" md

${ }^{67} \mathrm{Neml}, 27 / 54$

${ }^{68}$ Yıldırım, Celâl, İlmin Işığında Asrın Kur'anTefsiri, Anadolu Yayınları, İzmir, trs., IX, 4482.

${ }^{69}$ Meryem, 19/20.

${ }^{70}$ Meryem, 19/28.
} 


\section{DEĞERLENDIRME ve SONUÇ}

Kur'ân-1 Kerîm'de bahsi geçen ahlâkî öğretilerin yapısını daha iyi anlamayı amaçladığımız yukarıdaki pasajlarda, ayetlerde kullanılan kelimelerin yapısını "iffet" ve "hayâ" kavramları özelinde inceledik. Okuyucuların zihninde bu kelimeler üzerinden bütüncül bir çıkarım oluşturmayı amaçladığımız çalışmamızda yer alan kavramların etimolojik özelliklerine büyük yer ayırdık. Bu sebeple, yukarıda yer alan değerlendirmelerimizin öz itibariyle etimoloji ağırlıklı bir içerik taşıdığını söyleyebiliriz.

Özellikle, ahlâkî öğretilerin insanlar tarafından rehber addedilme noktasında önem görmesi ve hayata dair birçok gerçeği bünyesinde barındırması, bu zamana kadar yapılan araştırmaların önemini göstermektedir. Bizim araştırmamızda ulaşmaya çalıştı̆̆ımız nokta da Kuran'da yer alan ahlâkî öğretilerin daha iyi anlaşılmasına katkıda bulunarak, insanların bu kitabı yaşamlarına uygulamasına yardımcı olmaktır.

Kur'ân-1 Kerîm'de bazı ayetlerde görüldüğü üzere, muhataplardan belirli davranış ve alışkanlıklardan kaçınılması istenmiştir. 'Kumar oynamak', 'zina yapmak' 'içki içmek' gibi birçok davranışın yasaklanması bu ayetler vasıtasıyla muhataplara bildirilmiş ve onların bu davranışlardan kesin bir emirle uzak durması emredilmiştir. Bazı ayetlerde de aynı kavramlar kullanılarak insanların "iffetli olmak", "hayâ sahibi olmak", "adaletli olmak", "yoksullara yardım etmek" gibi bazı davranışlara yönelmesi istenmiştir. Ayrıca, Kuran'da yer alan bu ahlâkî temsiller öğretici üslupla okuyuculara aktarılmıştır.

Kitap'ta yer alan bu temsillerin insan hayatına olan etkilerinin daha iyi anlaşılabilmesi ve insanların bu temsilleri ne derecede ve nasıl hayatlarına uygulayabileceklerini öğrenmesi adına anlamsal içerik kadar kavramsal içerikte önem arz etmektedir. Bu noktada, geçmişten bugüne kadar, tefsir ve hadis literatüründe de kavramsal çerçevenin incelenmesine büyük önem verilmiştir. Biz de çalışmamızda bu literatürden mümkün olduğu ölçüde yararlanmaya gayret ettik.

Kur'ân-1 Kerîm'de yer alan ahlâkî öğretilerde sunulan temsillerin bir kısmında, çalışmamızın da konusu olan, "iffet ve "hayâ" kelimeleri araç olarak kullanılmıştır. Bu kavramlar muhataplara belirli sorumluklar yüklemiş olup, bu sorumlulukların, daha genel tabirle Kur'an'ın istediği yaşam tarzının daha iyi anlaşılabilmesi için kavramların etimolojik manaları üzerinde de çalışmalarda yapılmıştır. Çalışmamızın konusunu oluşturan ve Kur'ân-1 Kerîm'de birçok ayette geçen "iffet” ve "hayâ" kelimelerinin etimolojileri muhatapların Kuran'1 anlamlandırabilmesi adına büyük önem arz etmektedir.

Çalışmamız kapsamında ilk ele aldığımız ve genel manada "kötü söz ve fiillerden sakınmak" anlamına gelen "iffet" kavramının ve diğer kavram "utanmak, çekinmek" gibi anlamlara gelen "hayâ" kavramının, farklı veçhelerde kullanılmış olduğunu, değişik anlamları olduğunu izah ettik. Yukarıdaki pasajlarda değişik anlamlarından bahsettiğimiz bu kavramların ayetin anlam bütünlüğüne istinaden faklı kullanımları bulunduğunu ayrıca gördük. Geçtiği yerlerde hem aynı köklerden türetilen hem de farklı farklı köklerden türetilip, "iffet" ve "hayâ" kavramıyla aynı anlama gelen kullanımların da yer aldığını, anlam olarak bu kavramlara yakın kelimeler bulunduğu gibi zıt kelimelerin de bulunduğunu, ayrıca iki kavramın da anlam olarak birbirlerine yakın kullanımlarda kullanıldığını örnekleriyle beraber inceledik. 
Ayetlerdeki kullanımlarında "Sizden bekâr olanları, kölelerinizden ve cariyelerinizden durumu uygun olanlart evlendirin. Ĕger bunlar yoksul iseler, Allah onlar lütfuyla zenginleştirir. Allah, lütfu geniş olandır, hakkıyla bilendir. Evlenmeye güçleri yetmeyenler de Allah kendilerini lütfuyla zengin edinceye kadar iffetlerini korusunlar...", ${ }^{\text {,1 }}$ gibi yer yer teşvik, emir, yöneltme gibi manalarda kullanılan bu kavramlar, yer yer de "O sizi hep çirkin işler ve hayâsızlı yapmaya, bir de Allah hakkında bilmediğiniz şeyleri iddia etmeye teşvik eder" ${ }^{72}$ ayetinde olduğu gibi sakındırma, olumsuz vasıflandırma gibi anlamlara değinildiğini de gördük.

Sonuç olarak, bu çalışmayla birlikte Kur'ân-1 Kerim'de yer alan ahlaki öğretilerin "iffet" ve "haya" gibi kavramlar üzerinden muhataplara aktarıldığını, bu aktarımlar sırasında değişik anlatım yöntemlerinin izlendiğini ve bu anlatım özelliklerinin temelinde, Kur'an'ın öğretilerinin muhataplara daha anlaşılabilir bir düzeyde sunulma gayesi yer aldığını gördük. Bu amaçla, Kur'an'da yer alan birçok ayeti ve bu ayette kullanılan kavramlarla beraber, verilmek istenen mesajın sunuluş tarzını da bizâtihi inceledik. Yaptığımız bu çalışmanın, Kur'ân-1 Kerim'in oldukça geniş olan ahlâkî öğretisinin muhataplar tarafından daha doğru anlaşılabilmesi ve günümüz dünyasında daha doğru tatbik edilebilmesi adına önem taşıdığı kanaatindeyiz.

Temennimiz, Kur'ân-1 Kerîm'de yer alan ayetlerde kullanılan kavramların anlam içerikli çalışmalarla birlikte etimolojik içerikli çalışmalarında devam etmesidir. Zira insanların hayatlarında ortaya koyduğu ve karşılaştıkları fiillerin daha iyi anlaşılabilmesi, hayata ve diğer canlılara karşı davranışlarını nasıl şekillendirecekleri hususunun daha iyi anlaşılabilmesi hususunda bu çalışmalar önem arz etmektedir. Elbette geçmişten bu yana bilâd-1 İslam topraklarından çıkmış olan alimlerimiz, mütefekkirlerimiz ve araştırmacılarımız bu konulara ehemmiyet vermişlerdir. Fakat aynı ehemmiyet ve ciddiyet günümüz Müslümanlarının hayatı ve Kur'ân-1 Kerîm'de yer alan mesajları anlamlandırabilmesi adına da önem arz etmektedir.

\section{KAYNAKLAR}

Abduh Muhammed-Rıza Muhammed Reşid, Tefsîru'l- Kur'âni'l-Hakîm (Tefsîru'l-Menâr), Kâhire, Dâru'l-Menâr-Mektebetü'l-Kâhire, 1373/1953.

Abdulbaki Muhammed Fuad, el-Mu'cemü'l-Müfehres li Elfâzi'l-Kur'âni'l-Kerîm, Kahire, Dâru'l-Hadîs, 2001.

Ahmed Rifat, Tasvîr-i Ahlâk, İstanbul, Mahmud Bey Matbaası, 1309/1891. Sâdeleştirilmiş baskıs1: Tasvîr-i Ahlâk; Ahlâk Sözlüğ̈̈, Yayına Haz: Hüseyin Algül, İstanbul, Tercüman 1001 Temel Eser, yrs., trs.

Ali, Cevad, el-Mufașșal fî târîhi'l- 'Arab ḳable'l-İslâm, Beyrut, 1968-1973, IX.

Asım Efendi, el-Okyânûsu'l-Basît fî Tercemeti'l-Kâmûsi'l-Muhît, trc. Mustafa Koç- Eyüp Tanrıverdi, İstanbul, Türkiye Yazma Eserler Kurumu Başkanlığı, 2013, II.

Bayrakl1, Bayraktar, Kur'an Ahlâkı, İstanbul, Bayraklı Yay, 2011.

Beydâvî, Kâdî Nâsıruddîn Ebû Saîd Abdullah b. Ömer b. Muhammed eş-Şîrâzî, Envâru't-Tenzîl ve Esrâru't-Te'vîl, İstanbul, Dersaâdet Yayınları, trs.

\footnotetext{
${ }^{71}$ en-Nur 24/32-33.

72 el-Bakara 2/169.
} 
Cevherî, Ebû Nasr İsmail b. Hammâd, es-Sihâh, Tahkîk: Ahmed Abdülğafûr Attâr, Beyrut, Dâru'l-i̇lm li'l-Melâyîn, 1399/1979.

Çağrıc1, Mustafa, "Ahlâk", Türkiye Diyanet Vakfı İslâm Ansiklopedisi (DİA), İstanbul, Türkiye Diyanet Vakfi-1989., II.

Çağrıc1, Mustafa, "Hayâ", Türkiye Diyanet Vakfi İslâm Ansiklopedisi (DİA), İstanbul, Türkiye Diyanet Vakf1- 1997, XVI.

Çağrıcı, Mustafa, Anahatlarıyla İslâm Ahlâkı, İstanbul, Ensar Neşriyat, 3. Baskı, 2000.

Çağrıcı, Mustafa, İslâm Düşüncesinde Ahlâk, İstanbul, Birleşik Yayınları, 2000.

Çelik, İbrahim, Kur'ân Işı̆̆ııda Hoşgörü ve Şiddet, Bursa, Kişisel Yayınlar, 2001.

Çetin, Abdurrahman, "Takvâ", İslâm'da İnanç, İbâdet ve Günlük Yaşayış Ansiklopedisi, İstanbul, İFAV Yayınları- 1997, IV.

Draz, Muhammed Abdullah, Kur'ân Ahlâkı, Terc: Emrullah Yüksel-Ünver Günay, İstanbul, İz Yayınlar1, 1993.

Ferâhidî, Ebu Abdurrahman Halil b. Ahmed, Kitâbu'l-Ayn (nşr. Mehdi Mahzumi, İbrâhim Samerrai), Beyrut, Müessesetü'l-Alemi li’l-Matbûât, 1988, I.

Fîruzâbâdî, Mecduddin Muhammed b. Ya'kûb, Besâir Zevi't-Temyîz fì Letâifi'l-Kitâbi'l-Azîz, nşr. Muhammed Ali en-Neccâr, Beyrut, el-Mektebetü'l-İlmiyye, ts.

Gazzâlî, Ebu Hâmid Muhammed bin Muhammed, İhyau Ulumi'd-Din, İstanbul, Bedir Yayınevi, 1975.

Güneş Kadir, Arapça-Türkçe Sözlük, İstanbul, Ravza Yayınları, 2009.

Halebî, Ebü'l-Abbas Şehabeddin Ahmed b. Yusuf b. Abdiddaim Semîn, Umdetü'l-huffaz fí tefsiri eşrefi'l-elfaz (nşr. Muhammed Bâsil Uyûnü's-Sûd), Beyrut, Dârü'l-Kütübi'lİlmiyye, 1417/1996.

İbn Fâris, Ebu'l-Huseyn Ahmed b. Zekeriyyâ, Mû'cemu Mekâyîsi'l-Luga (nşr. Abdusselâm Muhammed Hârun), Beyrut, Dâru'l-Cîl, 1411/1991, II.

İbn Manzûr, Cemâlüddîn Muhammed b. Mükerrem Lisânu'l-Arab, Beyrut, Dâru'l-Fikr, 1414/1994, XIV.

İsfahânî, Ebü'l-Kāsım Hüseyn b. Muhammed b. el-Mufaddal er-Râgıb, Müfredâtü elfâzịi'lKur'ân (nşr. Safvân Adnân Dâvûdî), Dımaşk-Beyrut 1412/1992.

Kadı İyâz, eş-Şifâ bi Ta'rîfi Hukûki'l-Mustafâ, Tercüme ve Notlar: Suat Cebeci, Ankara, Rehber Yayınları, 1992.

Karahisârî, Mustafa b. Şemsüddin Ahterî, Ahterî Kebîr, İstanbul, Nadir Eserler Kitaplığı, 2014.

Karaman, Hayrettin vd., Kur'an Yolu Meâli, Ankara, Diyanet İşleri Başkanlığı Yayınları, 1.Basım, 2013.

Kılıç, Recep, Ahlâkın Dînî Temeli, Ankara, Türkiye Diyanet Vakfı Yayınları, 1996.

Kıllığlu, İsmail, Ahlâk-Hukuk İlişkisi, İstanbul, Marmara Ü. İlahiyat Fakültesi Vakfı Yayınları (IFAV), 1988. 
Kınalızâde, Ali Efendi, Ahlâk-ı Alậ, I-III (tek mücelled), Tashîh: Sa'dullah Saîd EfendiAbdülvehhâb Dağıstânî, Bulak, Bulak Matbaası, 1248/1832. Sâdeleştirilmiş baskısı: Ahlâk (Ahlâk-ı Alâi), Yayına Haz: Hüseyin Algül, İstanbul, Tercüman 1001 Temel Eser, 1989, I.

Kınalızâde, Ali Efendi, Devlet ve Âile Ahlâkı, Yayına Haz: Ahmet Kahraman, İstanbul, Tercüman 1001 Temel Eser, 1989, II-III.

Mutçalı Serdar, Arapça-Türkçe Okul Sözlüğü, İstanbul, Dağarcık Yayınları, 1997.

Müslim, Müslim b. Haccâc Ebu'l-Hüseyn, el-Câmiu's-Sahîh bi Şerhi'l-İmâm Muhyiddîn enNevevî, Beyrut, Dâru'l-Ma'rife, 1417/1996, I-XIX.

Sami, Şemseddin, Kâmûs-ı Türkî, İstanbul, Çamlıca Yayınları, 2016.

Seyyar, Ali, Ahlâk Terimleri (Ansiklopedik Sözlük), İstanbul, Beta Basım Yayım Dağıtım A. Ş., 2003.

Tirmizî, Ebû Îsâ Muhammed b. Îsâ b. Sevre (Yezîd), el- Câmiu's- Sahih, (nşr. Ahmed Muhammed Şâkir v.dğr.), Kahire 1356/1937.

Uludağ, Süleyman "Ahlak, Maneviyat ve Gündelik Hayat", İslam'a Giriş Temel Esaslar, Ankara, Diyanet İşleri Başkanlığı Yayınları, 2008.

Yazır, Elmalı1ı Muhammed Hamdi, Hak Dini Kur'an Dili, İstanbul, Eser Neşriyat, 1971, c. X.

Yıldırım, Celâl, İlmin Işı̆̆ııda Asrın Kur'ân Tefsiri, İzmir, Anadolu Yayınları, 1986.

Zebîdî, Muhibbuddîn Muhammed Murtazâ el-Huseynî el-Vâsitî, Tâcu'l-Arûs min Cevâhiri'lKâmus, (Thk. Ali Şîrî), Beyrut, Dâru'l-Fikr, 1414/1994, c. IX.

Zemahşerî, Ebu'l-Kâsım Cârullah Mahmûd b. Ömer, Esâsü'l-Belâga, Mısır, Dâru'l-Fikr, $1406 / 1985$, I.

Zengin, Fethullah, "Cahiliye Araplarında Bazı İyi Ahlâk Örnekleri ve Sebepleri Üzerine Bir Değerlendirme”, İstanbul, İ. Ü. İlahiyat Fakültesi Dergisi, 2016. 